\title{
()
}

Research Paper

EPRA International Journal of Economic and Business Review-Peer Reviewed Journal

Volume - 9, Issue - 5, May 2021 | e-ISSN: 2347 - 9671| p- ISSN: 2349 - 0187

\section{IMPACT OF THE FINANCIAL CONTROL OF MARKETING COMMUNICATION ACTIVITIES ON COMPETITIVE ADVANTAGE OF SAUDI SERVICE ORGANIZATIONS}

\author{
Dr. Majed A. Al Abdulkareem ${ }^{1}$, Prof. Iyad A. Al Nsour ${ }^{2}$ \\ ${ }_{1,2}^{2}$ Advertising and marketing Communication Department, School of Media and Communication \\ Imam Mohammad Ibn Saud Islamic University, Riyadh - KSA
}

\section{ABSTRACT}

DOI No: $10.36713 /$ epra6572

Article DOI URL: https://doi.org/10.36713/epra6572

This study aimed to determine the effect of financial control of marketing communication activities on the competitive advantage dimensions of services organizations in Saudi Arabia, as well as to investigate the statistical differences in the research variables according to some organizational factors. The study population consists of two parts, the first part represents the service organizations in Saudi Arabia reaches 206 in 2019, and the second part is the actual customers of such surveyed organizations in Riyadh city reaches 8 million in 2019. The full survey of all service organizations and the purposive sampling methods are used. The response rate of survived organizations reaches $64.5 \%$ of total surveyed organizations, while the sample size of customers is 1500 and $97.5 \%$ of total distributed questionnaires estimate 1463 questionnaires. The descriptive methodology is used and the questionnaire is the key tool to collect the primary data. The study concludes that there is it is found that there is a statistically significant effect of the financial control in the MC on the competitive advantage, the study also concludes that there are significant statistical differences in the financial control of MC Activities according to listed on the stock markets. Finally, the study suggests some recommendations that enhance the financial control of marketing communication activities in such organizations through increasing the efficiency of control systems for marketing communication activities, and give greater flexibility in budgeting and expected variations, and using the costbased strategy to maximize the business performance of such organizations.

KEY WORDS: Financial Control, Financial Planning, Business Performance, Marketing Communication, Competitive Advantage, Service Sector, Saudi Arabia.

\section{INTRODUCTION}

Marketing communication activities are one of the important tools that the organization has to define its businesses and products, as well as to influence consumer trends. These tools are designed to meet the planned objectives of the organization. Nor are these activities casual or reliable to communicators. It is an effective tool for increasing the organization's capacity in urgent situations and is used to mitigate the existing shocks and crises. So, the planning of marketing communication activities is seen as a massive necessity and not a choice (Thammer,2017,p.20). 
The literature indicates that the importance of planning marketing communication activities is growing in financial matters in the organization. Money is the core of the business and is one of the most key factors affecting the business performance. The availability of financial resources allocated to marketing communication activities within the organization cannot be justified by waste, poor expenditure or distribution, and must be linked to success or efficient use and optimal allocation (Nganga,Esther\&Njeru,2017,p.2).

Senior management in many businesses have monitored spending for marketing departments, determined and planned expenditures. The top management determines the maximum standards of control and accountability (Webber, 2002, p.705). Therefore, it is necessary to increase the level of financial control in marketing activities, to regulate management practices and to keep up marketing resources from waste and a miscalculation, as well as to avoid spending in bad areas can't achieve the planned objectives of the organization.

Recent management trends have contributed to strengthening financial control and turning it into a tool for tracking errors. It has become necessary to show those responsible for financial control, which is now seen as a source of improvement in performance, correction, and processing of deviation. These actions have helped many organizations to guard against external risks and to make sure that the organization's objectives are met. Here, studies confirm that financial control ensures that the Organization has a better competitive position in the market, enabling it to meet the targeted competitive advantage. So at the end; financial control of marketing communication activities may reinforce that belief and is a key and effective reason for doing so.

This process has become one of the most important requirements for entering the future, building competitive strategies (Assey,2014,p.15). When Saudi Arabia become one of the strong economies worldwide G-20 and, the corporate governance practices are required at this stage. Saudi companies need to divide financial resources, specifically to improve the marketing uses. Marketing activity is considered to guide the organization and enhance the success and effectiveness of the reaming activities (Qi,2010,p.121). Reducing the rate of financial failure among organizations and encouraging new competitors to enter the local market, this requires a change in working mechanisms, planning methods and performance control techniques (Alabdulkareem \& Alnsour,2020).

\section{RESEARCH STATEMENT}

Saudi Arabian service-sector organizations face many challenges and pressures. They are among the sectors most affected by globalization and the liberalization of international trade. This has forced them to coexist with the high competitiveness imposed by the open - employment system with competitors and put them in confrontation with larger organizations, which are better known for their brands. This has led them to improve their performance and seek their own competitive advantage.

Cost control and pressure is a priority for managerial planning, and it helps to achieve the competitive advantage of the cost-based organization and to working within the acceptable market limits. The data show that marketing communication activities share reaches $50 \%$ of the total marketing costs in the organization (Al Hamad, 2009). Failure in such a mission will destroy the organization. The studies show that the key reason for the failure of $70 \%$ of organizations in Saudi Arabia is financial waste, misallocation, and bad allocation of financial resources among marketing communication activities (AlJarousha, 2011).

The absence of control on the financial resources of marketing communication, and pass through the planned schedule, is a crucial factor that destroys the business performance. Negative deviations can drive up marketing costs, especially if marketing management applies the profit margin or cost-based pricing method. Even positive deviations may also press the estimated financial resources and idle allocations. This may prevent marketing management from taking advantage of available resources at the end of the fiscal year. This period is the most affordable for cost reduction at crisis and emergency times. Sometimes, the organizations canceled the advertising expenses in the last quarter of the year because it has no effect on business outcomes (Kotler, 2009, p.202).

Hence, the control function has become a key to the financial planning process for marketing communication activities (Foster, 2017, p.82). Which in turn increases the ability to track the performance of activities and controls deviations when they occur (Silva \& Jayamaha, 2012, p.12). This, in turn, assures those responsible for reviewing the work of the Organization about the level of commitment to what has been appreciated. Researchers at this place believe that statistical differences between the organizations examined in terms of performance and effectiveness and profit indicators are due to the level of control. The theoretical review confirmed the link between control and competitive advantage; it clearly indicates that successful and effective organizations are better able to 
cope with competitors and better allocation and channel their available resources (Al- Rabiawi et al., 2015, p.561).

In this sense; Saudi Arabian organizations that seek to keep up the domestic market and penetrate the international one; new methods are needed according to the quality and cost-based competition as important elements of customer attraction (Al-Amari et al. 2019; Ade et al., 2019). A few studies have looked at the impact of financial control of marketing communication activities. However, through the current study, the practical gap focus on resolve the impact of financial control on marketing activity can be filled by using the most important and contribution economic sector. It is the service sector. The questions of the study problem could therefore be formulated as follows:

$>$ To resolve the impact of financial control of marketing communication activities on the dimensions of competitive advantage (cost, quality, flexibility, delivery) in Saudi service organizations.

$>$ To find the statistical differences in the level of financial control of marketing outreach activities according to the type of ownership and the listing in the financial market.

\section{THE RESEARCH OBJECTIVES} objectives:

This study seeks to achieve the following

$>$ Determine the application level of financial control of marketing communication activities in Saudi service organizations.

$>$ Determine the level of competitive advantage of the Saudi service organizations surveyed.

$>$ Measure the impact of financial control of marketing communication activities on the competitive advantage of Saudi Arabian organizations.

$>$ Resolve the statistical differences in the level of financial control of marketing communication activities according to the type of ownership and listing in the financial market.

\section{THE RESEARCH SIGNIFICANCE}

The importance of the study follows:

$>$ It is one of the few studies at the domestic level that has studied directly the impact of financial control of marketing activities on competitive advantage. It is expected to give more knowledge to the marketing communication field. Financial control of marketing communication activities is a part of business plans. It helps to design fit strategies with customer needs and financial resources.

$>$ Financial control of marketing communication activities is one of the largest sources of expenses among the organizations. This study aims to cut the surpluses and money wasted. The expected outcome makes the financial control of marketing communication activities as rational management behavior for marketing managers and market-oriented organizations.

$>$ This study is allied on the main economic sector in the KSA. This sector has subsectors that have a high contribution to the local economy. Saudi Arabia looks for the service sector as a key pillar of economic reform in accordance with kingdom Vision 2030. The service sector is one of the most effective alternative solutions to cut the dependence on oil exports.

\section{LITERATURE REVIEW AND PREVIOUS STUDIES}

Financial control of marketing outreach activities:

Control is one of the four management functions used to make sure that the goals of an organization are achieved (Foster, 2017, p.82). Control is one of the scientific foundations that can be relied on. It provides the comparison between the real and planned performance indicators, explores the deviations and their causes in early time (Siam, 2009). According to this function, control determines responsibilities and duties for each organizational unit related to the cost issues (Tunji,2013, p.12). This delegation pushes organizational units to plan effectively and cut the difference between the real and estimated figures. Financial assessment of the activities of the organization; one of the most prominent tasks to carry out the plans, it is an essential platform for good performance, and a means to achieve the organizational goals. This control is carried out through a system of functions - coordination, organization, evaluation, and control - that allow for the assessment process in line with the functions of the organization.

Hope and Fisher (2003) considered the financial estimate as a financial plan and it is the performance management process leading to the implementation of what was planned. It includes goals to be achieved, resources to be assessed, and then the measurement and control of what is actually being implemented. However, studies that criticize the use of financial control, make people fear and rigid instructions that distort the changeable and updated work environment. Here, Tongi Tunji (2013) 
emphasizes the importance of flexibility, cut the rigid, hold up the mismatched estimates for the current time is time-consuming will destroy the control mission. The ability of workers to think creatively, create alternative solutions and generate lucrative investments is reduced. All of the above requires more spending and decreases the strict control of the financial deviations.

2.5 Impact of Financial Control on Competitive Advantage:

Organizations work in rapidly changing environments, pushing them to have a competitive advantage with new marketing advantages in their new markets (Nganga et al., 2017, p.2). Porter focused on competition as the core and outcome of a business, and its path to success or failure. This meaning that any marketing strategy in an organization must seek a competitive advantage that would achieve its profit goals and keep up its sustainable position in the market. Many studies link performance to competitive advantage, considering that good performance will lead to the competitive advantage of the organization. So competitive advantage is classified as a feature that distinguishes the organization from other competitors and enables a strong position in the market (Al-Khanq, 2005).

In another study, competitive advantage was defined as the ability to create and maintain a tenable position before competitors (Awwad et al., 2013, p.69). Kotler and Keller (2012) asserts that the competitive advantage of an organization means that it can do something better than competitors, giving it excellence and the ability to deliver. In the current study, the competitive advantage of an organization is seen as a feature or characteristic of which an organization is known in the market, a milestone that distinguishes it from competitors, and makes use of various resources and competencies to keep it.

The competitive advantage is related to the level of implementation of the different strategies and the size of operational and marketing tasks. Studies also confirm that the marketing communication strategy is part of the overall marketing strategy, contains sequential steps and is allocated funds that are appropriate to the operational instruments used (Kotler, 1999/2009, p.201). In this direction, financial estimate is the essential pillar of the control. This control aims to reduce the wasted and lost in activities and ensure optimal use of resources (Assey,2014, p.15). The effective and improved use of control will affect performance. The performance is the final outcome of the business efforts, especially the financial indicators (Masakala et al., 2017). Other studies emphasize the positive relationship between financial control, financial performance indicators and, in particular, profit rates, growth and liquidity (Joudeh and Attar, 2019).

On the other hand, control is linked to the number of non-financial indicators, including competition, which have been widely ignored by financial researchers (Qi, 2010, p.121). The marketing research has been concerned with competitive advantage. The study of Fahd (2019) in the Samarra State Pharmaceutical Company indicates a statistical impact of marketing communication and competitive advantage. The study of Al-Marshidi and Al-Otaibi (2017) confirmed the impact of market orientation on the competitive advantage of Saudi organizations listed in the financial market. In more detail, studies have shown the importance of differentiation and innovation for achieving competitive advantage. The results of the Sugiyartist study enhanced the impact of competitive advantages on overall marketing performance. The competitive advantage is one of the hallmarks of an organization that leads to a distinctive competitive position (Al-Khnaq, 2005, p. 39)

In more detail; competitive advantage contains a set of dimensions used to evaluate the business performance. Financial control of marketing communication activities can be linked to competitive advantage. Cost control, follow-up of deviations, and optimal distribution of resources can achieve competitive advantage (Awwad et al., 2013, p.71). The study of Alnsour (2016) is one of the most notable studies that has used the dimensions of competitive advantage: Quality, cost, flexibility, delivery. Studies suggest that that relationship is obvious between the two variables. Achieving competitive advantage and enhancing the performance of the organization requires efficient and effective use of resources as well as a continuous assessment of deviations. This can be achieved through control. The Joshi, Mudhaki, and Bremser (2003) study suggests that financial control helps control performance and deviations. The Qi study (2010) confirms that effective financial control has a positive impact on the performance of machine manufacturers. The Tunji study (2013) showed no impact of financial planning and control on the performance of the British company "Cadbury", and the effect of financial control on employees is proved. There are a few studies that support the positive relationship between financial control and the performance of the organization (Gundars, 2016, p.4), but the literature survey suggests that there is a significant lack of studies that have tested the impact of financial control of marketing communication activities on the performance of organizations (Qi, 2010, p.18). The theoretical gap is therefore clear in this study, which seeks to explore the impact of financial control 
of marketing activities on the competitive advantage of service organizations in KSA.

\section{RESEARCH MODEL}

The following figure shows the model used in the study and aims to determine the shape and direction of the relationship between independent and dependent variables.

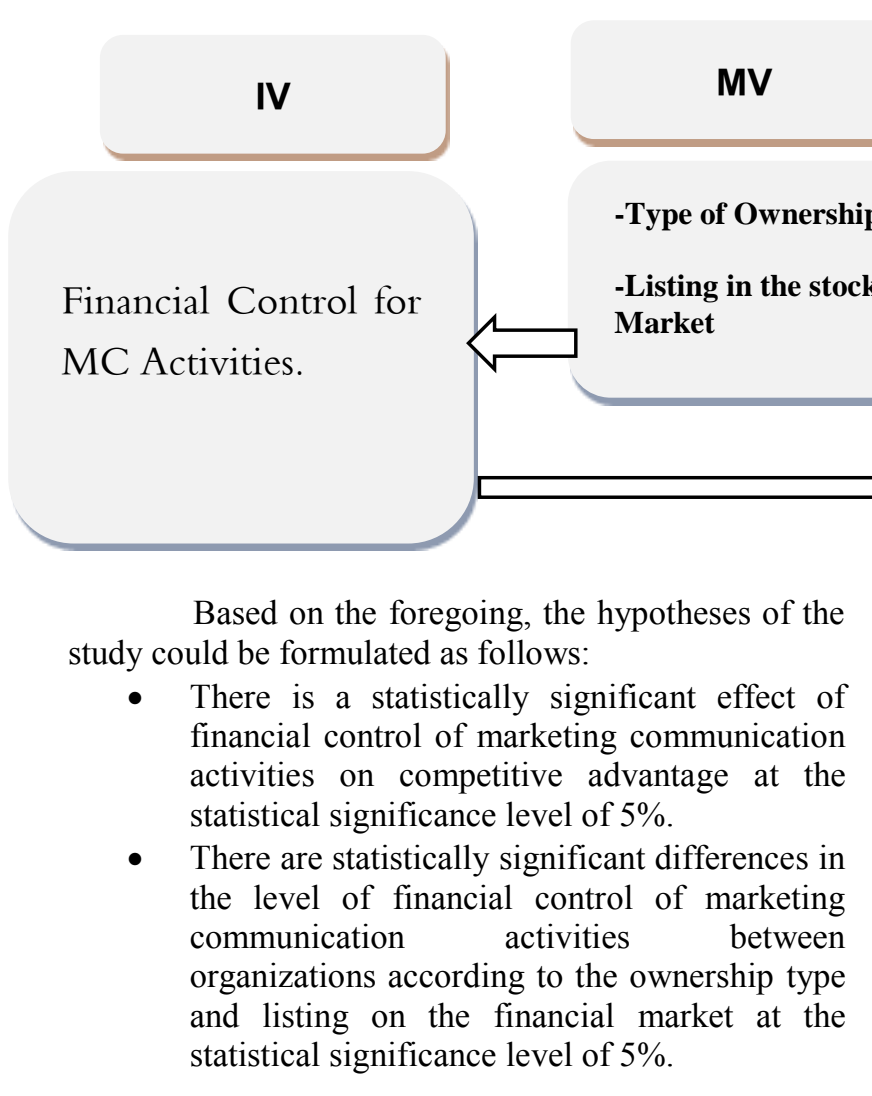

\section{FIELD STUDY}

1.7 Research Population: It consists of two parts:

$>$ The population of companies is composed of all organizations operating in the service sector in Saudi Arabia and subject to the General Agreement on Trade and Tariff in Services (GATTS), consisting of 10 sectors, which are divided between retailing, education and training, tourism and travel, transport, communications, electricity, health, finance, and sports (WTO,2005). The number of such organizations was 206. The study has already been carried out on Saudi organizations with public departments or branches in Riyadh. The data collected from this population related to the independent variable (financial control of marketing communication activities).

$>$ The population of customers is composed of all customers of service organizations, and the population of Riyadh is estimated to have reached $(8,100.629)$ in $2019(\mathrm{GSO}, 2019)$. The sample will be drawn from the age group older than 19 , accounting for $39 \%$ of Riyadh's total population, so the actual size of the population of customers is 3.159 .245 people. Data collected from such a population is related to the dependent variable (competitive advantage).

2.7 Research Sample:

1.2.7 The Sample of Companies: The comprehensive survey technique was used to draw the selected companies. Because of the difficulty of reaching all service organizations, researchers access 133 organizations or $62.63 \%$ of the population of organizations that provided the required data for the study. The unit of analysis in this population is the marketing managers and sales managers (or those on their behalf), and table 1 indicates the characteristics of this population.

$>$ The distribution by academic qualification is concentrated in the bachelor's degree holders at $66.9 \%$, the diploma holders at $13.5 \%$, and graduate studies at $9.8 \%$. This finding suggests that most of the directors are bachelor's degree holders, which shows that academic qualification is not a prerequisite for recruiting people to this position.

$>$ The distribution by experience indicates that about $27.8 \%$ have experienced between 5-10 years, about $25.6 \%$ have experience 15 years or more, compared to $24.1 \%$ who have experience under 5 years, and $22.6 \%$ have experienced between 10-15. In conclusion, there is a normal pattern of distribution of experience and lack of reliance on a particular age group in the organizations examined. 
Table (1): Characteristics of Managers in the surveyed Companies

\begin{tabular}{|c|c|c|c|c|c|c|c|}
\hline$\%$ & $\mathbf{N}$ & \multicolumn{2}{|c|}{ The Character } & $\%$ & $\mathbf{N}$ & \multicolumn{2}{|c|}{ The Character } \\
\hline 24.1 & 32 & Less than 5 & \multirow{6}{*}{$\begin{array}{c}\text { Years of } \\
\text { Experience }\end{array}$} & 1.5 & 2 & $\begin{array}{c}\text { Less than } \\
\text { Secondary School }\end{array}$ & \multirow{6}{*}{$\begin{array}{c}\text { Academic } \\
\text { Qualification }\end{array}$} \\
\hline 27.8 & 37 & $\begin{array}{c}5 \text { - less than } \\
10\end{array}$ & & 6.8 & 9 & Secondary School & \\
\hline 22.6 & 30 & $\begin{array}{c}10-\text { less than } \\
15\end{array}$ & & 13.5 & 18 & Diploma & \\
\hline \multirow{3}{*}{25.6} & \multirow{3}{*}{34} & \multirow{3}{*}{ More than 15} & & 66.9 & 89 & Bachelor & \\
\hline & & & & 9.8 & 13 & Master & \\
\hline & & & & 1.5 & 2 & $\mathrm{PhD}$ & \\
\hline 100 & 133 & To & & 100 & 133 & \multicolumn{2}{|c|}{ Total } \\
\hline
\end{tabular}

2.2.7 Sample of Customers: The "purposive sample" method has been used to draw the participants in this sample. A face-to-face resolution was distributed to customers in the main branches and headquarters of companies operating in Riyadh. This sample is among the non - probabilistic samples. One reason for using this sample is the difficulty of listing all names and addresses of customers and the privacy policy in surveyed companies. The unit of analysis in this population is a customer over 19 years of age who lives in Riyadh and has active dealings with the companies surveyed. The sample size is estimated at 1500 customers and 37 are missed. The remaining part is (1463) is the subject of the final analysis. Table 2 indicates the personal characteristics of this sample.

$>43 \%$ of customers are diploma holders, $45 \%$ a bachelor's degree holders, and $12 \%$ a graduate degree holders.

$>29.3 \%$ of customers have less than one year experience, $27.9 \%$ between 1-less than 3 years, $19.1 \%$ between 3 -less than 5 years, and $14.5 \%$ between 5 - less than 10 years, compared to $9.2 \%$ for 10 years experienced people.

Table 2: The Characteristics of Customers

\begin{tabular}{|c|c|c|c|c|c|c|c|}
\hline$\%$ & $\mathbf{N}$ & \multicolumn{2}{|c|}{ The Character } & $\%$ & $\mathbf{N}$ & \multicolumn{2}{|c|}{ The Character } \\
\hline 29.3 & 428 & Less than 1 & \multirow{5}{*}{$\begin{array}{l}\text { Years of } \\
\text { Dealing }\end{array}$} & 43 & 630 & Diploma & \multirow{5}{*}{$\begin{array}{c}\text { Academic } \\
\text { Qualification }\end{array}$} \\
\hline 27.9 & 408 & 1 - less than 3 & & 45 & 658 & Bachelor & \\
\hline 19.1 & 280 & 3 - Less than 5 & & 11 & 161 & Master & \\
\hline 14.5 & 212 & 5 - Less than 10 & & 1 & 14 & $\mathrm{PhD}$ & \\
\hline 9.2 & 135 & More than 10 & & & & & \\
\hline
\end{tabular}

3.7 The Measurement: The measurement tool is the questionnaire, it is developed to collect the required primary data, based on previous relevant studies. The five points Likert scale is used, which expresses the degree of response and the consistency between the statements and the respondent's opinions, where the value (5) is given for very high response, (4) is a high response, (3) is given for neutral response, the low response is given for the value (2), and the value (1) is given for very low response. In order to analyze the research results, the descriptive statistical analysis (arithmetic mean, standard deviation, and relative frequency) are calculated. The degree of response of the variables are evaluated according to the relative mean as follows: more than 4.2 is very high, (2) $4.2-$ more than 3.4 is high, (3) $3.4-$ more than 2.6 is average (moderate), (4) $2.6-1.8$ is weak and less than 1.8 is very weak.
4.7 The Reliability and Normal Distribution: Cronbach alpha is a measure of internal consistency, that is, how closely related a set of items are as a group. It is considered a measure of scale reliability. Cronbach alpha is not a statistical test, so it is a coefficient of reliability (or consistency). The Cronbach alpha coefficients of the research variables are between $0.761-0.923$.This means that the variables have relatively accepted. Internal consistency of all variables and all the coefficient values are statistically accepted since it is more than the statically permitted rate of $60 \%$ (Alnsour, 2016, p.8). The normal distribution test K-S is designed to ensure that data are normally distributed. The statistical rule states that data are normally distributed if the significance a level less than 5\% (Abdurrahman, 2013, p.56), the results of which show that all study variables are normally distributed according to the statistical rule used. 
Table 3: Cronbach Alpha \& K-S

\begin{tabular}{|c|c|c|c|}
\hline The Variables & K-S & $\begin{array}{c}\text { Cronbach } \\
\text { Alpha }\end{array}$ & Items \\
\hline Financial Control of MC Activities & $\mathbf{0 . 0 0}$ & $\mathbf{0 . 9 0 5}$ & $\mathbf{9}$ \\
\hline Competitive Advantage & 0.00 & 0.923 & 24 \\
\hline Cost & $\mathbf{0 . 0 0}$ & $\mathbf{0 . 8 0 3}$ & $\mathbf{5}$ \\
\hline Quality & $\mathbf{0 . 0 0}$ & $\mathbf{0 . 8 7 2}$ & $\mathbf{8}$ \\
\hline Flexibility & $\mathbf{0 . 0 0}$ & $\mathbf{0 . 8 0 3}$ & $\mathbf{5}$ \\
\hline Delivery & $\mathbf{0 . 0 0}$ & $\mathbf{0 . 7 6 1}$ & $\mathbf{6}$ \\
\hline Total & $\mathbf{0 . 0 0}$ & $\mathbf{0 . 9 4 9}$ & $\mathbf{3 3}$ \\
\hline
\end{tabular}

\section{RESEARCH VARIABLES}

1.8 Independent Variable (Financial Control of Marketing Communication Activities):

Table 4 indicates that the response degree to the "financial control" axis was an average accounting record (3.87) and a standard deviation (1.14), which means that the level of financial control of marketing communication activities is high. This IV has 9 items that have very high, high, and low levels of response. The item 1 and 6 have low levels of response. The arithmetic mean of the IV ranged between 4.82 and 2.45 .

Table 4: The Descriptive Statistics of IV (Financial Control of MC Activities)

\begin{tabular}{|c|c|c|c|c|c|c|c|c|c|}
\hline \multirow[t]{2}{*}{ Item } & \multicolumn{5}{|c|}{ Responses } & \multirow[t]{2}{*}{ Mean } & \multirow[t]{2}{*}{ S.D } & \multirow[t]{2}{*}{ Decision } & \multirow[t]{2}{*}{ Rank } \\
\hline & $\begin{array}{l}\text { Very } \\
\text { Low }\end{array}$ & Low & $\begin{array}{l}\text { Mediu } \\
\mathrm{m}\end{array}$ & High & $\begin{array}{l}\text { Very } \\
\text { High }\end{array}$ & & & & \\
\hline $\begin{array}{l}\text { The Department of Marketing uses the } \\
\text { approved budget as a benchmark for } \\
\text { evaluating the performance of operational } \\
\text { activities }\end{array}$ & 28 & 26 & 29 & 8 & 10 & 2.45 & 1.19 & Low & 9 \\
\hline $\begin{array}{l}\text { Your company has continuously } \\
\text { evaluations and calculations of deviations. }\end{array}$ & 1 & 4 & 15 & 38 & 41 & 4.17 & 1.1 & High & 3 \\
\hline $\begin{array}{l}\text { There is a follow-up process to implement } \\
\text { the estimated budget and periodic reports } \\
\text { requesting clarification of deviations. }\end{array}$ & 5 & 5 & 15 & 37 & 38 & 3.98 & 1.01 & High & 6 \\
\hline $\begin{array}{l}\text { The reasons for the actual deviation from } \\
\text { the estimate are discussed transparently } \\
\text { by the competent authorities. }\end{array}$ & 0 & 1 & 1 & 14 & 84 & 4.82 & 1.17 & Very High & 1 \\
\hline $\begin{array}{l}\text { The responsibility of those involved in } \\
\text { deviating from the estimated balance is } \\
\text { clearly defined }\end{array}$ & 4 & 2 & 15 & 26 & 53 & 4.24 & 1.03 & High & 2 \\
\hline $\begin{array}{l}\text { Deviations in the evaluation results are } \\
\text { treated as important and equal. }\end{array}$ & 23 & 23 & 35 & 14 & 5 & 2.55 & 1.16 & Low & 8 \\
\hline $\begin{array}{l}\text { The bodies involved in implementing the } \\
\text { budget take corrective action for } \\
\text { deviations }\end{array}$ & 3 & 5 & 17 & 35 & 51 & 4.04 & 1.19 & High & 4 \\
\hline $\begin{array}{l}\text { The normal extent of deviations from the } \\
\text { estimated balance of marketing } \\
\text { communication activities can be accepted } \\
\text { (up to } 10 \% \text { ) }\end{array}$ & 7 & 5 & 15 & 37 & 37 & 3.92 & 0.99 & High & 7 \\
\hline $\begin{array}{l}\text { External environmental developments are } \\
\text { taken into account when reviewing budget } \\
\text { deviations }\end{array}$ & 4 & 5 & 15 & 30 & 46 & 4.10 & 1.20 & High & 5 \\
\hline Total & 8 & 8 & 17 & 26 & 40 & 3.87 & 1.14 & High & \\
\hline
\end{tabular}

2.8 Competitive Advantage:

The Customers' responses to this DV have an average mean reaches 3.45 . This means that the competitive advantage of the surveyed organizations has a high degree of response with approval by $53 \%$ of the customers. Most service organizations operating in Saudi Arabia have a competitive advantage from the 
customers' perspective. In more detail, there are four dimensions of competitive advantage as follows:

- Quality is the set of characteristics that distinguish the product and are designed to fulfill the customer's needs and encourage frequent purchase (Pastengi, 2014, p. 202). This variable has an arithmetic mean reaches 3.55 , which means that the response level was high.

- Flexibility: It refers to the ability to produce a wide range of products, offer new products, rapidly adjusted existing products as well as respond to customer needs (Alnsour, 2016, p.7). This variable has an arithmetic mean reaches 3.52 , which means that the response level to this dimension was high.

Table 5: The Descriptive Statistics of DV (Competitive Advantage)

Item

The company you're dealing with provides services fit your expectations.

The company you're dealing with measures your satisfaction on an ongoing basis.

The company you're dealing with provides a continuous improvement in the service quality provided.

The company you're dealing with provides services through qualified personnel capable of meeting your expectations.

The company's products you're dealing with have no defects or errors compared to competitors.

The company you're dealing with is good for your satisfaction.

The Company you're dealing with provides services with a quality that increases your trust and confidence.

The Company you're dealing with provides services with a manner that meets your needs and wishes.

Total Quality Dimension

The company you're dealing with provides services that respond to changes in your expectations.

The company you're dealing with provides services that respond to market changes.

The company you're dealing with predicts your needs and your wishes for service to adjust its services The company you're dealing with is adjusting its services because of feedback.
- Delivery: means the concentrate on reducing the lead time and speed in designing new products, and delivering them to customers as soon as possible (Alnsour, 2016, p.7). The variable has an arithmetic mean reaches 3.51 , which means that the response level to this dimension was high.

- Cost: means the ability to manage production costs effectively, rigid control of costs and deviations and detailed control reports explaining responsibilities (Awwad et al., 2013, p71). This variable has an arithmetic means reaches 3.9, which means that the response degree to this dimension was moderate.

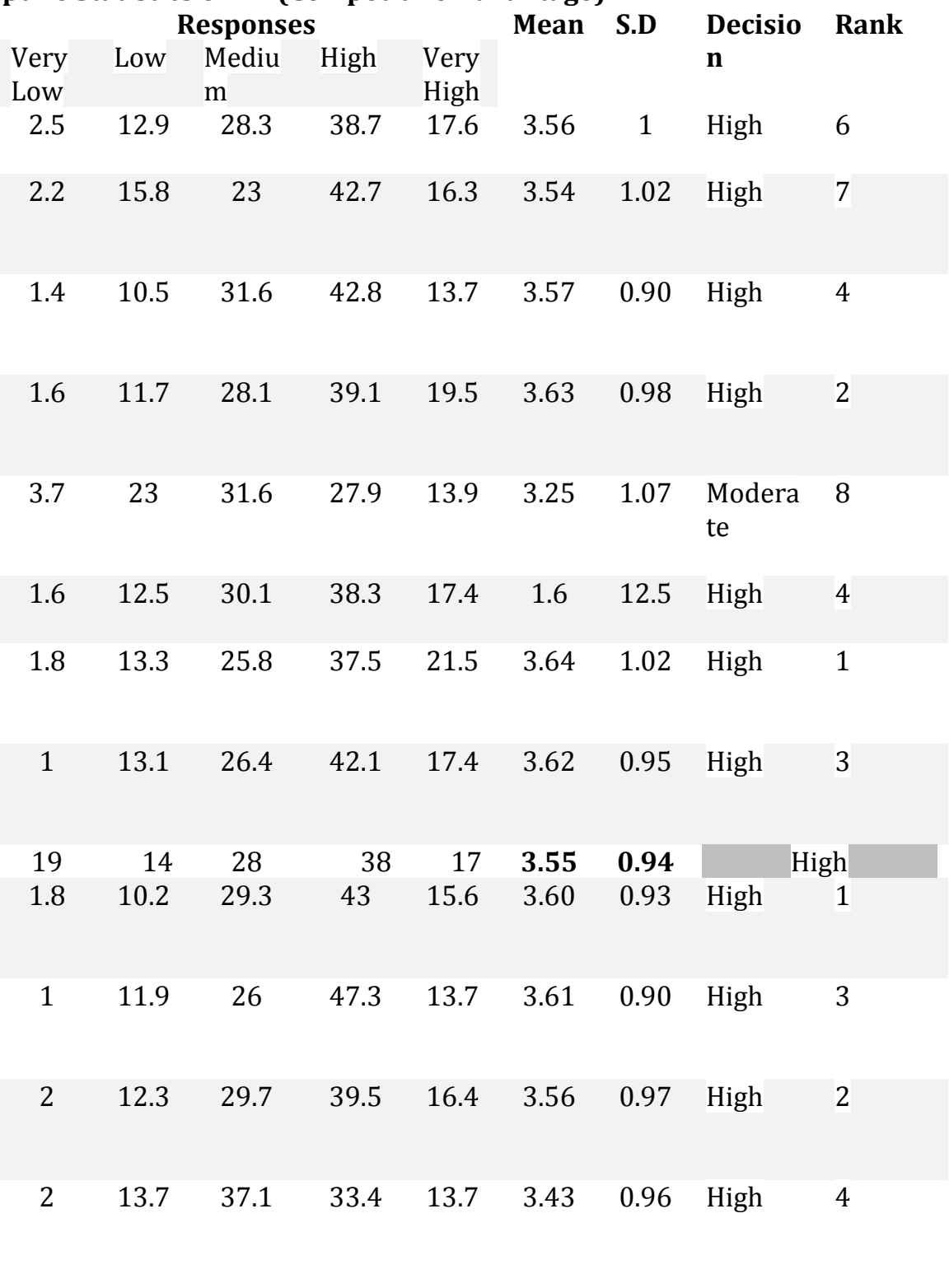


The company you're dealing with shapes its products in a short period of time

Total Flexibility Dimension

The company you're dealing with provides timely service

The difference between waiting for and getting service is better than competitors

The company you're dealing with has better ability to answer your query and complaints than competitors.

The company you're dealing with is committed to providing timely aftersale services.

The company you're dealing /with is self-serving, so you can get your needs on time

The company with which you are dealing is fully bound by the dates and places of delivery of its services

Total Delivery Dimension

The company you're dealing with is the lowest price for its services

The company you're dealing with makes ongoing promotional offers.

The company you're dealing with provides innovative services

The company offers the possibility of reducing services to reduce price

The company offers multiple purchase options for low prices.

Total Cost Dimension

Total Competitive Advantage

\begin{tabular}{|c|c|c|c|c|c|c|c|c|}
\hline 4.3 & 19.3 & 29.7 & 31.1 & 15.6 & 3.34 & 1.09 & $\begin{array}{l}\text { Modera } \\
\text { te }\end{array}$ & 5 \\
\hline 2 & 13 & 30 & 38 & 14 & 3.51 & 0,99 & \multicolumn{2}{|c|}{ High } \\
\hline 1.4 & 10.2 & 20.5 & 45.3 & 22.5 & 3.77 & 0.96 & High & 2 \\
\hline 1.6 & 15 & 32.8 & 36.1 & 14.5 & 3.47 & 0.97 & High & 3 \\
\hline 2 & 17.2 & 33.6 & 29.5 & 17.6 & 3.43 & 1.03 & High & 5 \\
\hline 3.3 & 14.3 & 34.6 & 31.8 & 16 & 3.43 & 1.02 & High & 4 \\
\hline 10.5 & 22.1 & 23.8 & 27 & 16.6 & 3.17 & 1.24 & $\begin{array}{l}\text { Modera } \\
\text { te }\end{array}$ & 6 \\
\hline 1.6 & 8.4 & 21.5 & 44.7 & 23.8 & 3.81 & 0.95 & High & 1 \\
\hline 3 & 14 & 27 & 35 & 18 & 3.51 & 0.99 & \multicolumn{2}{|c|}{ High } \\
\hline 3.1 & 15.4 & 27.5 & 37.9 & 16.2 & 3.49 & 1.03 & High & 2 \\
\hline 1.2 & 17.8 & 23.8 & 43.2 & 13.9 & 3.51 & 0.98 & High & 1 \\
\hline 2.7 & 18.2 & 34 & 33 & 12.1 & 3.34 & 1 & $\begin{array}{l}\text { Modera } \\
\text { te }\end{array}$ & 3 \\
\hline 2.5 & 16.4 & 40 & 30.1 & 11.1 & 3.31 & 0.96 & $\begin{array}{l}\text { Modera } \\
\text { te }\end{array}$ & 4 \\
\hline 5.7 & 19.9 & 26 & 35.2 & 13.1 & 3.30 & 1.10 & $\begin{array}{l}\text { Modera } \\
\text { te }\end{array}$ & 5 \\
\hline 3 & 17 & 30 & 36 & 13 & 3.39 & 1.04 & Mod & rate \\
\hline 2 & 15 & 29 & 37 & 15 & 3.49 & 1.02 & & gh \\
\hline
\end{tabular}

To test this hypothesis, a simple linear regression method has been used, which seeks to analyze the relationship between the IV and the DV and to predict the values of the DV according to IV (Boldaway, 2008, p. 99). Table (6) shows the statistical results of the main hypothesis as follows:

\section{TESTING HYPOTHESES OF STUDY}

1.9 First Hypothesis: There is a statistically significant effect of financial control of marketing communication activities on competitive advantage at $5 \%$ statistical significance level.

Table 6: Statistical Indicators of First Hypothesis

IV STATISTICAL INDICATORS

\section{DECISION}

\begin{tabular}{lccccccc|l}
\hline & $\mathbf{t}$ & $\mathbf{B}$ & $\mathbf{S i g}$ & $\mathbf{F}$ & $\mathbf{R}^{\mathbf{2}}$ & $\mathbf{R}$ & Sig. & THERE IS A \\
& 9.836 & 0.847 & 0.000 & 12.069 & 0.53 & 0.73 & $\mathbf{0 . 0 0}$ & \\
$\begin{array}{l}\text { Financial Control } \\
\text { of MC Activities }\end{array}$ & & & & & & & & \\
\hline
\end{tabular}


The results in table 6 show that the first hypothesis was associated with a strong statistical relationship with the dependent variable by $73 \%$, and the independent variable explained $53 \%$ of changes in competitive advantage. The results add that the impact factor $B$ indicated that the variation of the independent variable by one unit would change the competitive advantage by 0.847 units. This means that the impact on competitive advantage is less than the impact on the independent variable. In other words, the financial control of marketing activities within the organization provides a value-added competitive advantage. In order to test the hypothesis, the statistical rule states that the probability level of error should be less than 5\%, and therefore the significant level of financial control of marketing communication activities (0.00) is less than $5 \%$. Therefore, the study accepts the hypothesis says that there is a statistically significant effect of financial control of marketing communication activities on the competitive advantage at $5 \%$ statistical significance level.

In this hypothesis, the matrix between financial control of marketing communication activities and the four dimensions of competitive advantage was calculated. Table 7 shows a statistically significant correlation at the significant level $(0.01)$ between financial control of marketing communication activities, cost and delivery dimensions by 0.907 and 0.837 ), respectively, while correlations with quality and flexibility dimension have not been confirmed.

9.2 Second hypothesis: There are statistically significant differences in the level of financial control of marketing communication activities according to the ownership type and listing in the financial market at the statistical indicative level of 5\%.

In order to test this hypothesis, a test " $t$ " was used for two independent samples (Independient Sample t-test) if the variables have two choices of answer and the data were normally distributed
(Shahrani, 2018). This is condition is approved in this hypothesis. Table 8 indicates that the probability of error was 0.519 , which is greater than $5 \%$. So the hypothesis about the differences of IV according to the ownership type was rejected. The researchers believe that State-owned organizations may be more subject to accountability than other organizations. The controlling of sources such as expenditures and expenses, in particular, with State regulatory bodies such as the Office of the Superintendent General, which monitors State-owned organizations as compared to non-stateowned organizations. Overall, financial control is increasingly important in the urgent and difficult times when economic crises exist (Becker et al., 2015, p. 1).

On the other hand, the other part testing the differences in the financial control of marketing communication activities according to listing in the financial markets. The significant level of the listing organizations in the financial market (0.014) was found to be less than 5\%. According to the statistical rule, the hypothesis has approved that statistical differences in the level of financial control of marketing communication activities according to the listing organization in the financial market. The researchers explain that organizations listed in the capital markets have a higher degree of control than others. This is consistent with Joshi, et al. (2003) who found that there are differences between listed and nonlisted companies in terms of control. Companies on the financial market are subject to a higher level of accountability from shareholders, senior management, and the legislature, and are subject to Saudi corporate governance regulations and laws. Corporate Governance requires disclosure and transparency of its financial position, allowing shareholders to assess their investments periodically. This result makes control and control of expenditure within the organization a necessary procedure.

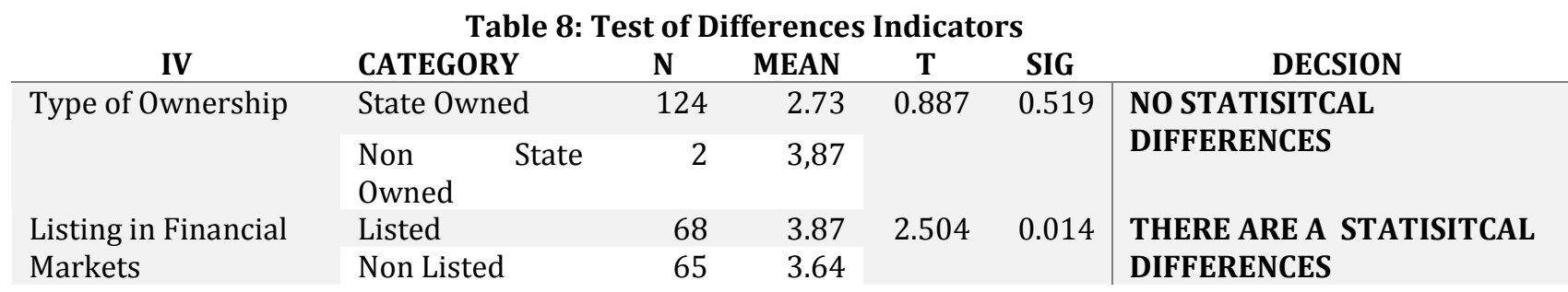

\section{DISCUSSION AND RECOMMENDATIONS}

The results show that the financial control of marketing communication activities was highly degreed according to marketing departments of the surveyed organizations. This means that there is enough awareness from marketing departments about the importance of control practice for marketing communication activities. This result is consistent with a number of studies, including (Debebe \& Osebo, 2019 Foster, 2017; Silva \& Jayamaha, 2012), but on the contrary with the Qi study (2010). Financial control is used as a tool to monitor deviations and assess the performance of operational activities in the Organization. The results indicate a decrease in the level of financial control of marketing communication 
activities in some of the surveyed organizations. This means that these organizations are not aware of the importance of the commitment of the estimates, which is consistent with the study of Sylva and Jayamaha (2012). In the Joshi study, et al. (2003), which was applied to a similar Gulf countries environment, the reports of control were important evidence for assessing managers' abilities. The results showed that there was a clear decrease in accountability for saving financial resources, and the crucial dealing with positive deviations is absent. Positive deviations mean saved money on marketing communication resources.

However, the problem is how to link such precautions with performance, success, and achieving the marketing and communication objectives of organizations. Such organizations require clear principles to distinguish between negative and positive deviations. The surprise was that organizations with positive deviations have no accountability for that, so it is an indication of senior management's satisfaction with such practices. There was no difference between non-state-owned and state-owned organizations. The results confirm that there is a statistically significant correlation between the financial control of marketing communication activities, cost, and delivery, while there are no correlations with quality and flexibility these findings confirm that there is wide attention to regulatory systems and the intensive roles lead to enhanced competitive and cost-effective advantage.

The results of the study confirm the importance of quality and it has an average arithmetic mean comparing to the other dimensions of competitive advantage. The current study considers that this is a positive sign of the response of the surveyed organizations to the requirements and market conditions imposed by the laws of the rival and the requirements of the world trade organization WTO. This legislation revolves around the importance of quality-based competitiveness. This result is consistent with the (Alnsour, 2016; Boustanji, 2014). While the result of the Fahd study (2019) show the quality a low level of importance.

The results of our current study confirm that the organizations consistently measure customer satisfaction in continuous manners, and this confirms the interest in feedback from the customer and the attempt to use the information in developing the products for its customers. Sometimes, however, the customer shows that there are errors and defects in the products offered by their organization compared to competitors. This result is highly related to the nature of the service product. It is very important to show that service in nature is intangible, with no standardization as well as imperishability. These services are humanbased, so they vary from one to another, and the level of judgment differs from one customer to another as well. Organizations can upgrade quality by relying on a preventive model not curative. This may lead to avoiding future errors or defects, and this supports the positive relationship with the customer. The last conclusion is consistent with Sugiyarti (2018) which emphasizes that broken and damaged products will cut quality control.

The level of flexibility based on competitiveness has been high, and there is no doubt that the surveyed organizations have the advantage of changing and adjusting their products, the quick responses to the changes in customers' preferences. The delivery advantage is one of the competitive bases for highly competitive and successful organizations in the market, especially with the rapidly changing preferences and tastes of customers (Pastengi, 2014, p202). The two researchers in the study say that the high level of flexibility is associated with enough marketing labor and human cadres to deliver suitable products for expectations. The correct polarization of human cadres, giving them enough flexibility and the responsibilities required for their work are key signals for flexibility in delivering the product. The human reason should use the given responsibilities moderately, no prejudice of the working rules, or deviates from the general goals of the organization increases the level of flexibility and competitive effectiveness. This result is consistent with (Alnsour, 2016; Boustanji,2014). Organizations often lack the flexibility-based competitive advantage in the short term because of weak marketing communication, shortage the technical, financial, or human factors. Regardless of the causes of flexibility-based competitive advantage, the current study confirms that it is a negative indicator that requires quick treatment and re-engineering the marketing and communication goals and product designing.

On the other hand, the results showed a rise in delivery-based competitive advantage that was high in the surveyed organizations. This result is consistent with (Fahd, 2019; Alnsour, 2016; Boustanji, 2014). The study of Diab (2014) had rejected such a result. The recognition of time as a productive source of competition by the organizations seems one of the success factors. Acquisition time is very important for financial control and it leads to non-price competition. The responses of surveyed organizations have reduced the importance of providing their products in a timely manner. This may be a negative indicator affecting long-term competitive advantage. There is a massive need for production automation and the use of sophisticated creative systems to deliver products in an easy way for targeted customers in the time and place. Those elements are 
sufficient to build a competitive advantage based on delivery and non-price led in the competitive market.

Finally, the cost-based competitive advantage has a moderate level of responses. These results did not reflect the actual market situation and competitors. The lack of awareness by surveyed organizations about cost-driving strategy is crucial. Price competition is based on the control ability of an organization to squeeze the cost level in a timely manner. With that result, there is an agreement with Diab (2014), Alnsour (2016), and Idris et al., (2017), but it was in line with Al-Marshidi and Al-Otaibi (2017). Participants' responses confirm that the organizations are unable to offer varied options for buyers can reduce the paid price For example, some organizations lack e-services through different websites or applications, and bad uses for e-marketing techniques. We add that the surveyed organizations have not taken into consideration the purchasing power of the Saudi buyers. Avoiding the needs diversification and market fragmentation and circumstances of the customers are key success factors in the middle and long run time. The market segmentation offers varied products with more price options, and it may reduce the gap with the buying capabilities. These automated practices will enhance the level of customer satisfaction, loyalty, and retention.

According to the findings, the study recommends that:

$>$ Increasing the efforts of financial control of marketing communication activities and the building of a well-established regulatory infrastructure for regulatory systems, supported by follow-up and analytical competencies.

$>$ Providing a degree of flexibility for planned deviations in the estimated marketing communication budgets to more suitable for changing the marketing environment.

$>$ Clear determining for the responsible person / Department about marketing communication activities. This procedure is one of the assessment and evaluation criteria of marketing communication performance.

$>$ Increasing the preventive measures that reduce financial deviations. This may avoid all undesired expenses, bad costs, and urgent losses.

$>$ Customer satisfaction is a key element of organizational success and competitive advantage. There is a massive need for a clear and effective feedback policy.

$>$ The highly automated programs for services provided in an easy way.

$>$ Focusing on cost strategy as an important tool for competitive advantage in Saudi Market. It is a very efficient policy comparing to non-price competition techniques.

$>$ Using the preventive management strategies to avoid the future defects and production mistakes.

\section{REFERENCES}

1. Abdulrahman, T. (2013). Guide to the Design and Implementation of Research in the Social Sciences, Institute of Public Administration: King Fahd National Library

2. Ade, L., and Akanbi A., and Tubosun, A. (2017).The Influence of Marketing Intelligence on Business Competitive Advantage A Study of Diamond Bank. Journal of Competitiveness, 9 (1), 51-71. DOI: 10.7441/joc.2017.01.04.

3. Al - Boustanji, G. (2014). The use of the Islamic Marketing Mix in building the competitive advantage in the Saudi Telecommunications Organization. Journal of Humanities and Social Sciences, Imam Mohammed bin Saud University, 31, 191-234.

4. Al - Marshidi, K., and Al - Otaibi, A. (2017). Market Orientation and Competitive Advantage. Arab Journal of Management, 37 (2), 67-90.

5. Al-Rabiawi, S., Abbas, H., Al-Ameri, S. and AlZubaydi, S. (2015). Marketing Management, Dar Ghaeda. Ammam.

6. Alabdulkareem, M., and Alnsour, I. (2020). The Impact of Financial Integration in the IMC Model on Business Performance: Evidence from Saudi Arabia. EPRA International Journal of Economic and Business Review, 8(9), 10-19. DOI: $10.36713 /$ epra3440

7. Al-Hamad, A. (2009). Factors Affecting the Selection of Advertising Media by International Advertising Agencies. Unpublished Master's thesis, Imam Mohammed bin Saud Islamic University. Riyadh, KSA.

8. Al-Jarousha, Y. (2011). The Absence of Strategic Planning Caused the Failure of $70 \%$ of Saudi Arabia's Organizations. Riyadh Gazette. Retrieved from: http://www.alriyadh.com/619260

9. Al-Khnaq, S. (2005, March). Strategic Performance and Competitive Advantage. Paper presented to the International Scientific Conference on Outstanding Performance of Organizations and Governments, University of Warqala, Algeria, March 8-9, 200.

10. Al-Nsour. I., (2016). Impact of the Blue Ocean Strategy on the Competitive Value of Saudi Commercial Banks. Arab Journal of Economics and Management, (2), 1-15.

11. Assey, D. (2014).Effectiveness Of Budgeting Process in Achieving Organizational Goals: A Case of Temesa". A Dissertation Submitted in Partial. Unpublished master Dissertation. University of Tanzania.

12. Awwad, A., Khattab, A., and Anchor, J. (2013).Competitive Priorities and Competitive Advantage in Jordanian Manufacturing. Journal of 
Service Science and Management, 6, 69-79. DOI:10.4236/jssm.2013.61008.

13. Baldawi, A. (2008). Applied Statistical Methods. Palestine: $\quad$ Sunrise Publishing House - Trading. (2019). the transport sector. The companies listed in the 2019 trading are recovered from: https://cutt.us/aN5O5.

14. Becker, Sebastian \& Mahlendorf,Matthias \& Schaffer,Utz \& Thaten,Mario.(2015). Budgeting in Times of Economic Crisis. Contemporary Accounting Research, retrieved from: http://ssrn.com/abstract $=2605359$

15. Debebe, A., and Osebo, G. (2019). Impact of Budgeting Process on Organizational Effectiveness. Journal of Economics and Sustainable Development, 10(1).1-9. DOI: 10.7176/JESD.

16. Eitzel, M., Wurker, B., and S, W. (2006). Lebanon Library Publishers.

17. Fahd, O. (2019). Role of Marketing Mix Elements in Enhance Competitive Advantage. Iraqi Journal of Market Research and Consumer Protection, 11(1), 48-64.

18. Foster, T. (2017).Budget Planning Budget Control Business Age and Financial Performance in Small Businesses. Unpublished Ph.D. Dissertation, Walden University: College of Management and Technology, USA:Minnesota.

19. Gundars, B., (2016). Strategic Planning. Leonardo da Vinci Programme Project development and Approbation of Applied Courses Based on the Transfer of teaching Innovations in Finance and Management,Universy of Latvia,Riga

20. Hope, J. and Fraser, R. (2003).Beyond Budgeting how managers can break free from the annual performance trap. USA: Harvard Business.

21. Idris, A., and Abdullah, R. (2017). Quality of banking services and their impact on competitive advantage.

22. Joshi, P.L., Al-mudhaki, J., and Bremser, W. (2003).Corporate Budget planning control and performance evaluation in Bahrain. Managerial auditing journal, 18(9), 737750.DOI:10.1108/02686900310500505.

23. Joudeh , A., and Attar, K. (2019). The Extent of Applying the Planning Budgets in Banks Operating in Jordan and its Impact on profitability. Lighthouse Magazine, 25 (1), 379-30.

24. Joudeh, A., and Abu Sardaneh, J. (2010). Evaluation of the Planning Budget System in the Greater Amman Municipality. Journal of AlBassaer, 13 (2), 237-29.

25. Kotler , P., and Dubois , B. (2000). Marketing Management.10e Editions, Paris PubliUnion.

26. Kotler, Philip. (2009). How to Create, Invade and Control Markets. Translated by Faisal Abdullah Babacar. Riyadh: Gareer Library.

27. Kotler, $P$ and Keller, K. (2012).Marketing Management, $14^{\text {th }}$ Edition, New Jersey: Pearson Education.

28. Kotler, P., Armstrong, G. (2007). The Basics of Marketing. Riyadh: Mareekh Publishing House.
29. Kotler, P., Saunders, J., Aarmstrong, G., and Bong, F. (2006). 2006). Marketing. Aladdin Publishing House.

30. Libby, T., and Lindsay, M. (2010). Beyond Budgeting or Budgeting Reconsidered? A Survey of North-American Budgeting Practice. Management Accounting Research, 21, 56-67.

31. Masakala, C., Wauyo, F., Omol, E., and Okumu, J. (2017).The Role of Budgeting Process in Financial Mbale Uganda. American Journal of Finance, 1(3), 31-48.

32. Nganga, L., Waiganjo, E., and Njeru, A. (2017). Influence of Organizational Resources Portfolio on Organizational Performance in Tourism Government Agencies in Kenya. International Journal of Business and Commerce, 6(4), 1-17

33. Qi, Y.(2010). The Impact of the Budgeting Process on Performance in Small and Medium Sized Firms in China. Unpublished Ph.D. Dissertation, Holland:Twente University.

34. Siam, W. (2009). Extent of Use of Discretionary Budgets in Planning, Control and Decision-Making in Jordanian Public-Contributing Pharmaceutical Companies, Administrative Sciences Studies, 36 (2), 416-44.

35. Silva , L.M.D. and Jayamaha, A., (2012) .Budgetary Process and Organizational Performance of Apparel Industry in Sri Lanka .Journal of Emerging Trends in Economics and Management Sciences,3(4),354-360.

36. Sugiyarti, G. (2018). Product Competitive Advantage Anteceden for Successful Marketing Performance. Scholars Journal of Economics Business and Management, 5(10), 893-903. DOI: 0.21276/sjebm.2018.5.10.1.

37. Tamimi, K. (2018). Marketing PR, Contemporary Vision. United Arab Emirates, Book House

38. Thammer, K. (2017). Marketing Communication Policy Planning in Electronics Producing Enterprises. Amarabak, Journal of the American Academy of Science and Technology, 8 (24), 19-30.

39. Tunji, S. (2013). The Impact of Budgeting and Budgetary Control on the Performance of Manufacturing Company in Nigeria. Journal of Business Management Social Sciences Research, 2(12), 8-16.

40. Weber, J. (2002). Managing the Marketing Budget in a Cost-Constrained Environment. Industrial Marketing Management, 31(8), 705-717. 